\title{
Development Strategy for Superior Cassava Products for MSMEs in Deli Serdang Regency
}

\author{
Remus Hasiholan $\mathrm{P}^{1}$, HB.Tarmizi ${ }^{2}$, Rahmanta $^{3}$, Agus Purwoko ${ }^{4}$ \\ Student of Doctoral Program of Regional Planning, Universitas Sumatera Utara ${ }^{1}$ \\ Lecturer of Doctoral Program of Regional Planning, Universitas Sumatera Utara ${ }^{2,3,4}$ \\ \{remus.pardede2014@gmail.com ${ }^{1}$ \}
}

\begin{abstract}
Cassava is one of the superior commodities of MSMEs in Deli Serdang. The existence of government regulation of Deli Serdang which stipulates cassava as the superior product of Deli Serdang has not maximally helped MSMEs in developing superior products of cassava as a quality processed product and failed in increasing MSMEs income. It is necessary to know how the strategy for developing superior products of MSMEs in Deli Serdang. The purpose of this research is to find aspects of internal and external environmental consist of strengths, weaknesses, opportunities and threats for the development of superior products of Deli Serdang MSMEs, which can used to improve quality and competitiveness. The approach used in this research is descriptive qualitative with the SWOT analysis. The results show that the superior cassava product development program has 8 strength factors, 10 weakness factors, only 5 opportunity factors and 5 threat factors which indicate that the development of superior cassava products has not succeeded. The findings require a strategy to increase the strength factor, overcome shortages, face threats and increase opportunities by formulating 10 strategies for developing program of superior cassava products and increasing income.
\end{abstract}

Keywords: Development Strategy, Superior Products, Small Industry, SWOT Analysis

\section{Introduction}

Deli Serdang Regency is one of the areas that is preparing itself to become a developing area to improve the welfare of its people. Various efforts have been made by the government, one of the efforts is to develop areas based on superior commodities in Deli Serdang which involve Deli Serdang MSMEs. The aim is to manage the development of a mainstay area to increase the competitiveness of the area and its superior products.

Through Regent Decree No. 553.A year 2018 defined chips and opak as Deli Serdang's superior products so that SMEs can maximize their business by utilizing cassava as the main raw material for processing chips and opak.

However, Deli Serdang MSMEs has various limitations in developing its business. Capital, technology, innovation, marketing constraints and a lack of knowledge about development strategies are common obstacles faced by MSME players processing this cassava product. The 
income of this chips and opak businessman is still small. It is known that the low turnover of cassava raw material UMKM actors, the average turnover of MSMEs Deli Serdang players is very low $<$ Rp. 50,000,000, it is Rp. 14,321,918, - [1] They need assistance in processing cassava products as superior products that have added value for sale.

In an effort to help chip and opak entrepreneurs in Deli Serdang, the government is trying to empower these micro-scale businesses to increase their income. One of these empowerment efforts is by utilizing regional superior commodities that have the potential to be developed and have profitable market potential. It is stated that the development of superior commodities and the development of MSMEs are effective strategies for regional economic development [2].

It is known that entrepreneurs in cassava processing products in Deli Serdang do not have the right strategy to develop processed cassava products because of their limitations so that input or several alternative strategic solutions are needed to improve cassava processing apart from becoming chips and opak. These MSMEs players need encouragement to develop their businesses and industrial centre for cassava processing products in Deli Serdang which are highly competitive by involving local community initiative and participation, improving the quality of human resources, utilization of economic, social, technological and institutional resources (association).

Based on this background, this research aims to answer the problem of how to develop a superior cassava product development strategy to support the development of the mainstay area of industrial centre in Deli Serdang. This study will later analyse various aspects of the internal and external environment which are the strengths, weaknesses, opportunities and threats for the development of superior cassava products in supporting the development of the mainstay industrial area in Deli Serdang. The existence of this development strategy will be able to encourage Deli Serdang entrepreneurs to produce highly competitive processed cassava products.

\section{Literature Review}

Micro, Small and Medium Enterprises (MSMEs) are business activities capable of expanding employment, providing broad economic services to the community, playing a role in the process of equalization and increasing community income, encouraging economic growth, and playing a role in realizing national stability [3].

Micro enterprises have an important role in economic development, because of the relatively higher labor intensity and smaller investment, so that micro enterprises are more flexible in dealing with and adapting to market changes. Therefore, the development of microenterprises can contribute to economic diversification and structural changes as a precondition for long-term stable and sustainable economic growth. In addition, the level of job creation is higher in micro enterprises than in large companies [4].

In developing their business, MSMEs face various obstacles both internally and externally, these problems include: accessibility, management, capital, technology, raw materials, information and marketing, infrastructure, bureaucracy and fees, partnerships.

\subsection{Superior Sector}

The leading sector is usually associated with a comparison, be it a regional, national or international comparison. In the international sphere, a sector is said to be superior if it is able 
to compete with the same sectors as other countries. Whereas in the national scope, a sector can be categorized as a leading sector if a sector in a certain region is able to compete with the same sector produced by other regions, both in the national and domestic markets [5].

Leading sectors are confirmed to have greater potential to grow faster than other sectors in an area, especially the existence of supporting factors for these superior sectors, they are capital accumulation, absorbed labour growth, and technological progress. The creation of investment opportunities can also be done by empowering the potential of the leading sectors owned by the region concerned [6]. A leading sector is a sector whose current existence has played a major role in the economic development of a region, because it has advantages or criteria. Furthermore, this factor develops further through investment activities and becomes the cornerstone of economic activity. Therefore, leading sectors are an important part of regional economic development.

\subsection{Superior Commodity}

A superior commodity is a potential commodity that is considered to be competitive with similar products in other regions, because besides having a comparative advantage it also has high business efficiency [5]. Superior commodities are the results of community businesses that have high marketing opportunities and are profitable for the community.

\subsection{Superior Product Development}

Regional Superior Products according to the Minister of Home Affairs Regulation No. 9 of 2014 Article 1 paragraph (2) is a product, both in the form of goods and services produced by cooperatives and small and medium enterprises that have the potential to be developed by utilizing all resources owned by the region: natural resources, human resources and local culture and generating income. for the community and local government.

Various factors determine Regional Superior Products, as stated in the Regulation of the Minister of Home Affairs Number 9 of 2014 concerning the determination of Regional Superior Products, among others: employment; b. contribution to the economy; c. regional economic base sector; d. renewable; e. socio-cultural; f. market availability; g. raw material; h. capital; i. production facilities and infrastructure; j. technology; k. business management; 1. price.

\subsection{SWOT Analysis}

SWOT analysis (Strengths, Weaknesses, Opportunities, and Threads or Strengths, Weaknesses, Opportunities and Threats) is an analysis that is part of obtaining strategic planning methods in evaluating the strengths, weaknesses, opportunities and threats of a project or business [7]. Through a SWOT analysis, the objectives of the activity or project will be specified to identify various internal and external factors that are good or not good in achieving the goal. This SWOT analysis is also a tool to support decision making and determine the most appropriate strategy based on logic to maximize strengths and opportunities and at the same time weaken the deficiencies (weaknesses) and threats faced by a business / activity so that it succeeds in achieving goals or increasing competitiveness. 


\section{Research Method}

This research is descriptive in nature with the aim of describing and finding a systematic, factual and accurate description of various nature facts and the relationship between research phenomena. This study took a sample of 100 people who were selected by purposive sampling who were considered able to answer all the authors' questions and were able to extract information about the development of superior cassava products in Deli Serdang. Data obtained through interviews with respondents.

The data analysis technique used is a SWOT analysis which is aimed at analysing various internal and external factors of cassava processing business actors in Deli Serdang so that information can be obtained about various factors which are strengths, weaknesses, opportunities and threats that can be used to increase regional competitiveness. small industry. Based on the results of this SWOT analysis, various alternative competitive strategies for the product will be obtained.

\section{Result and Discussion}

Based on the results of the interview, it is known that there are 8 internal factors that can be the strength to develop the business of processing superior cassava products in Deli Serdang. Some of the known strengths are (1) the ease of obtaining raw materials. Deli Serdang is a centre for superior commodities in the form of superior cassava products. (2) the majority of people in Deli Serdang are specialists in the processing of cassava products such as opak and chips (3) innovation of processed products in the form of flavours, shapes and types of processing other than opak and chips (4) sufficient labour is available so that MSMEs entrepreneurs can assisted in efforts to process superior cassava products (5) the form and process of transportation owned by entrepreneurs to distribute processed products that are good and fast so that processed products can be quickly delivered to consumers (6) production equipment is also well available because the processing of cassava products is quite easy it is still quite simple because it is still minimal adoption of processing technology, because it is still a household production.

Other strengths are known; (7) the entrepreneurs of cassava processing products are the original people of Deli Serdang so that they are familiar with the tastes and needs of Deli Serdang consumers in particular, so that they can make processed cassava products according to the interests and tastes of consumers which will support increased sales (8) sufficiently skilled work in processing cassava into various types of processed products.

Other internal factors that can be a weakness in the development of superior cassava products in Deli Serdang are (1) the management of small entrepreneurs is still minimal so that the cassava processing business actors still have a weak structure and management for developing business capacity and resources including resources. human (2) simple means of production so as not to keep up with technological innovations. Many entrepreneurs still use simple processing machines without the latest technology, so that it slows down production (3) low quality standardization of packaging and products so that it does not attract consumers' interest (4) the selling price of products is still not able to increase the income of sellers or entrepreneurs, but if it is raised there is a concern. will not sell because it is considered to exceed the standard price capacity (5) processed products are still dominated by chips and opaque so that other processed sweet potato products are still minimal due to the lack of assistance for innovation (6) distribution is not optimal because processed cassava products 
are still dominated by Deli Serdang consumers have not fully reached consumers outside of Deli Serdang even though the promotional costs incurred are quite large but have not been able to attract consumers from outside Deli Serdang to buy or make them by typical of Deli Serdang (7) additional materials used to support raw material processing is still considered inadequate to produce delicious and varied processed cassava Serdang no. 553.A in 2018 determined chips and opak to be the superior products of the Deli Serdang area (9) there is still a lack of support from financial institutions and the government for business capital support for cassava product entrepreneurs so that many business actors are constrained in their business development, even though operational costs are high. great if you want to meet the innovation of processed cassava production (10) the enthusiasm of entrepreneurs is low in innovating.

As for identified 5 external factors that become opportunities for the development of superior cassava products in Deli Serdang, namely (1) local government support with the issuance of Regent Decree No. 553.A of 2018 which stipulates chips and opak as superior products of Deli Serdang (2) there is government support by providing training and education institutions to assist entrepreneurs in adopting technology and developing processing innovations (3) the ease of bureaucracy in obtaining business permits and leniency of credit business of financial institutions (4) competitive climate and conducive business environment in Deli Serdang (5) availability of industrial centre or hawker centre provided by the government as a means of promotion to support business development and increase sales of processed cassava products.

Other external factors that are considered as threats have also identified 5 factors that could threaten the sustainability of the development of superior cassava products in Deli Serdang, namely (1) changes in people's taste for food types (2) the existence of processed product certification regulations that can hinder the development of home industries such as cassava processing (3) the economic crisis and the unpredictable pandemic (4) technology that is far from the reach of the competence of entrepreneurs (5) processed food products from ingredients other than cassava that are far more modern and appetizing (fast food) which can be obtained at a low price.

Based on the results of the SWOT analysis carried out, it is known that the development of this superior cassava product requires the right strategy so that the industrial centre for cassava processing products or small entrepreneurs in Deli Serdang has succeeded in increasing competitiveness, namely (1) it is necessary to increase the industrial process network (agroindustry). starting from upstream to downstream starting from suppliers of raw materials to marketing processed products to consumers (2) there must be innovation in product processing, taste and packaging so that it attracts consumer interest (3) improving the way products are processed with the same quality standards (4) open, accept and apply the latest processing technology to produce attractive product innovations (5) provide locations for industrial centre or hawker centre as areas for promotion of processed cassava products (6) motivate entrepreneurs to diligently attend training, seminars to build networks / relationships and to improve understanding in the production process up to $t$ business management (7) creates various promotional media such as leaflets, brochures or using technology in the form of online mass media or social media that are currently in vogue such as Instagram, WhatsApp, or Facebook (8) collaborating with the government, including government agencies. tourism, cooperative offices, and hotels to promote processed cassava products (9) create quality standards and certification of processed products in order to expand market reach outside Deli Serdang or even on an international market scale (10) add and improve the quality of infrastructure including business land. However, there are additional strategies that 
can be used as input for entrepreneurs, government or association institutions, namely (11) building cooperation with various employers' associations (12) collaborating with various training and development institutions to support diversification and innovation of products and packaging that are hygienic, of quality , durable, certified at affordable prices (13) assistance from the government, agencies or associations in order to fulfil product certification to meet product standard qualifications in marketing.

The results of this study are supported by [8], stated in their research that the development of superior commodities with the addition of added value and high selling value to processed products requires a strategic role in the production process that involves the role of capital, infrastructure, technology, human resources. , raw materials and additives [8]. There is even a need for the availability of a market that can accommodate products for consumers to buy. Wisardja also stated in his research that success in developing the wood industry in Gianyar Bali requires the support of an industrial environment consisting of customers, suppliers, competitors and technology [9]. Sukesti and Iriyanto in their research stated that the strategy for developing superior commodities must involve culture and local wisdom, which requires cooperation between entrepreneurs, government, institutions and the community[10]. It takes training, technology, information, access to finance, marketing access assistance that is fulfilled. The results of this study is supported by Munizo because in his study it is stated that entrepreneurs must be consistent in increasing their business growth with strategies for increasing capital, training, manpower, collaborating with the government and associations, having business locations and market information [11].

The role of the market and government is very important in supporting entrepreneurs to develop regional superior products. The wider the market availability, the greater the potential for the processed product to be superior. However, there are several obstacles that can be faced with regard to market access, namely limited information and inflexible sources of information for entrepreneurs, even the limited acceptance of information means that entrepreneurs are not open to changes or technology so that the information received is not applied [12].

Deli Serdang itself has implemented Regent Decree No. 553 A of 2018 which states that the superior regional products are chips and opaque. The government has even provided an industrial centre for processing this cassava product (Opak Village) and a hawker centre by Khas Deli Serdang as support for the development of superior cassava products in Deli Serdang. This means that MSMEs entrepreneurs receive full support from the government for their business development by fully involving the main raw material for cassava as a superior product in the Deli Serdang area.

\section{Conclusion}

The results of the SWOT analysis conclude some information in this study, namely that the development of superior cassava products in Deli Serdang has 8 internal factors as strengths, 10 internal factors as weaknesses, 5 external factors as strengths and 5 external factors as threats. So, based on analysis and observation, 10 main strategies were formulated with the addition of 3 supporting strategies that could be emphasized for government and association support because they were an important institutional factor to support business development by utilizing regional superior products (cassava) in Deli Serdang. The implementation of this strategy with a high commitment from cassava processing product entrepreneurs together with the government and associations will be able to develop superior products in Deli Serdang that 
have high competitiveness and high selling value to help increase income or the economy of small entrepreneurs.

\section{Acknowledgements}

The author would like to thank all those who support this research to be carried out and produce the right information. This research may be far from perfect, so that for any deficiencies in the writing of the results of this study, the authors apologize.

\section{References}

[1] Dinas Koperasi UKM Deli Serdang, "Data UMKM Pengelola Ubi Kayu.” 2019.

[2] E. A. Antara, "Pengembangan Komoditas/Produk/Jenis Usaha Unggulan UMKM Di Provinsi Bali," Lap. Penelit. Bank Indones. Denpasar Bekerja Sama Dengan Lemb. Penelit. Dan Pengabdi. Kpd. Masy. Univ. Udayana., 2011.

[3] I. P. Hidayat and A. R. Fadillah, "Pengaruh Penyaluran Kredit Usaha Mikro Kecil Menengah (Umkm) Dan Pendapatan Operasional Terhadap Laba Operasional (Kasus Pada Pt.Bank Jabar Banten Tbk)," Digital Library Fakultas Ekonomi Jurusan Akuntansi Universitas Siliwangi, 2009. .

[4] J. Sutrisno and S. Lestari, Kajian Usaha Mikro Indonesia. 2006.

[5] T. T. H. Tambunan, Globalisasi dan Perdagangan Internasional. Jakarta: Ghalia Indonesia, 2004.

[6] D. J. Rachbini, Pengembangan Ekonomi \& Sumber Daya Manusia. Jakarta: Grasindo, 2001.

[7] F. Rangkuti, Analisis Swot: Teknik Membedah Kasus Bisnis. Jakarta: PT. Gramedia Pustaka Utama., 2014.

[8] Kusdiana and Gunardi, "Pengembangan Produk Unggulan UMKM Kabupaten Sukabumi," Trikonomika, vol. 13, no. 2, pp. 153-171, 2014.

[9] I. W. Wisardja, "Analisis Lingkungan Industri Kerajinan Ukiran Kayu Di Kabupaten Gianyar Propinsi Bali,” Brawijaya, 2000.

[10] S. D. Iriyanto, "Pemberdayaan UKM: Meningkatkan Komoditas Unggulan Ekspor UKM Dalam Rangka Pengembangan Ekonomi Daerah. Seminar Nasional Ilmu Ekonomi Terapan. Fakultas Ekonomi UNIMUS." .

[11] M. Munizu, "Pengaruhfaktor-Faktor Eksternal Dan Internal Terhadap Kinerja Usaha Mikro Dan Kecil (Umk) Di Sulawesi Selatan,” J. Manaj. dan Kewirausahaan, vol. 12, no. 1 , pp. 33-41, 2010.

[12] Fasyah and E. Al, "Determining The Main Product Of Micro Small And Medium Enterprises Agro Industry Sector In Bogor District,” Manaj. IKM, vol. 11, no. 2, 2016. 